\title{
Financial Inclusion and Economic Growth in Uganda A case study of selected districts in Western Uganda
}

\author{
Marus Eton ${ }^{1}$, Gilbert Uwonda ${ }^{2}$, Fabian Mwosi ${ }^{3}$, Godfrey Barigye ${ }^{4}$ and Patrick Bernard Ogwel ${ }^{5}$ \\ ${ }^{1,4}$ Kabale University, Kabale Uganda \\ ${ }^{2}$ Gulu University, Gulu Uganda \\ ${ }^{3}$ Bishop Barham University College, Kabale Uganda \\ ${ }^{5}$ Kampala International University \\ Kampala Uganda
}

\begin{abstract}
The study was conducted to examine the role of financial inclusion in economic growth basing on selected districts from western Uganda. The researchers adopted a cross-sectional survey design and both quantitative and qualitative approaches were used in data collection and analysis. The study used simple random and purposive sampling techniques to select a total of 194 respondents. The findings revealed that financial inclusion is significant in supporting economic growth; it upholds equitable distribution of growth benefits, transforms peoples' way of living, enhances capital creation and empowers people to go for financial services that are germane to their needs. The study indicated that Uganda's population living below the poverty line is falling, which sounds precise in the context of national income but very unseemly in the context of household income. While there are indicators of reduced constraints to accessing to working capital, reduced constraints to accessing financial services, effective use of economic resources to produce goods and services, those in business do not see the efficacy by government agendas geared to supporting international trade or investment. The study, therefore, recommends that there is a need for the government to review and redesign her policies on international trade business and support for homegrown investments. There is a need for quantitative metrics to ascertain the extent to which household income is proportional to national income. Several papers have recommended government interventions in financial accessibility.
\end{abstract}

Key words: Financial Inclusion, Financial Services, Economic Growth, Gross Domestic Product.

\section{INTRODUCTION}

Financial inclusion has been broadly recognized as critical in achieving economic growth. When citizens adopt a good financial system they are able to start and expand their businesses, manage risk and absorb financial shocks [1]. Strengthening Financial Inclusion is one of the initiatives in Bank of Uganda's Strategic Plan 2012-2017 issue paper no.2 [2]. The Financial inclusion agenda in Uganda has been under discussion since 2012, when the central bank of Uganda launched the financial inclusion project, whose overall objective was to increase access to financial services and empower the users of financial services to make rational decisions in their personal finances so as to contribute to economic growth. Globally 2.5 billion people are financial excluded; approximately $80 \%$ in Sub-Saharan Africa as compared to $8 \%$ in the high income organization of Economic Cooperation and Development (OECD) countries, and in Uganda, $80 \%$ have no access to mutually exclusive bank financial services $[1,2]$. The depth of Uganda's financial system is relatively low compared to average financial depth of low income countries within Sub-Saharan Africa. According to [3], financial inclusion is important to a country in terms of economic growth and development of the country. It enables to reduce the gap between the rich and the poor population and it's the robust pillars of progress, economic growth and development of the economy. Constructing a financial inclusion index to measure the level of financial inclusion, [4] tried to find out the relationship between financial inclusion and economic growth. Their argument was that, when people access banking services it benefits them to bank their money in the formal financial institutions, this results in high growth through multiplier effects. Economic growth is necessary to increase both household incomes and financing of public investment and social service delivery and is therefore a central objective of the National Development Plan of Uganda. Like 
many developing countries, Uganda has undergone a major economic transformation to develop market-based institutions [5, 6, 7]. The economy of Uganda advanced by 6.8 percent in the $3^{\text {rd }}$ quarter of 2018 following an upward revised $5.2 \%$ expansion in the previous period, it was the strongest growth rate since the last quarter of 2014[8]. The Gross Domestic product (GDP) growth is expected to be above 5 percent in 2018 and could rise further to 6 percent in 2019 [9]Uganda's main sources of growth has been good economic policies that led to increase in agricultural incomes, foreign direct investment, remittances by Ugandans living abroad and the high growth of the real estate sector [10]. It's also believed that Uganda's economic growth has been partly driven by private sector investment increment in the areas of construction and support from development partners in the areas of public sector spending on social services. In spite of the high regard given to financial inclusion as an integral part of development agenda in the world, the level of financial inclusion still remains low, with about two billion people having no bank accounts [1]. [11] observed that Uganda has made improvements over the years, in terms of financial delivery outlets/channels offered by both the formal and informal financial institutions. Financial stability of emerging countries also construes financial inclusion institutions as increasingly important investment vehicles for households and the public.

\section{PROBLEM STATEMENT}

The Government of Uganda's policy on increasing the level of financial literacy, financial consumer protection and supporting financial institutions innovative technology to increase access to financial services across all income segments in Uganda, is intended to increase Financial Inclusion to all [11]. The inability to access formal financial services has been identified as a key barrier for socio-economic development of developing economies such as Uganda [12, 13, 14, 15]. Access to formal banking services still remains very low, at only $20 \%$ predominately in urban locations, indicating high levels of exclusion from the formal financial system [16]. According to [11], Uganda has made improvements over the years in terms of financial delivery outlets/channels offered by both the formal and informal financial institutions. Despite the significant efforts and innovations in the financial sector to improve Financial Inclusion over the years, Ugandan economy is still struggling with the challenge of low levels of Financial Inclusion, with $80 \%$ of Uganda's adult population and the majority living in the rural areas have no access to formal banking financial services and this, therefore affects economic growth $[16,17,15,3]$. It's upon this background that the researchers investigated the contribution of financial inclusion in supporting economic growth in selected districts in western Uganda.

\section{OBJECTIVE OF THE STUDY}

To establish the contribution of financial inclusion in supporting economic growth in Western Uganda

\section{LITERATURE REVIEW}

\subsection{Financial Inclusion}

The term financial inclusion has taken on a multitude of meanings. A review of literature reveals that there is no universally accepted definition of financial Inclusion (FI). The Financial Inclusion can be defined as "the pursuit of making financial services accessible at affordable costs to all individuals and businesses, irrespective of net worth and size respectively [2]. Ensuring the usage and relevance of financial products and services available, focusing on the role of individual attributes needs to be considered by the financial institutions and policy makers respectively, to achieve more effective financial Inclusion (FI) [18]. Similarly,[19] noted that for an individual to get proper benefits of financial products and services, all should be easily accessible, cheap and relevant to individual needs. Access to financial services enables the transformation of lives of the low income earners in developing countries like Uganda. Similarly, [1] observed the inadequate knowledge about the macro-level effects of Financial Inclusion stems, in part, from the challenges associated with measuring it to a consistent basis both a cross countries. Accordingly ,[22]noted that inadequate knowledge makes citizens, especially those with low income not access mainstream financial products such as bank accounts, credit, payments services, insurances and financial advisory. Financial inclusion enables individuals to participate in the growth process by enhancing their access to economic opportunities and broadening their choices, which ultimately makes them more productive and efficient economic agents. An inclusive financial system helps socially omitted individuals to assimilate into the economy by creating opportunities for everyone [20]and thus results in more equitable dispersal of growth benefits. In a related view, [21], observed that it's not possible to attain the goal of inclusive economic growth, without active involvement of the excluded and marginalized. Relatedly, [22, 23]observed that financial sector development promotes propoor and equitable economic growth.

Financial Inclusion has a high beneficial effect on economic growth. According to [24], financial Inclusion had the potential to enhance economic growth and development. The authors also noted that Financial Inclusion is a huge prerequisite for economic growth and development based on its ability to enhance capital creation, financial sector savings and intermediation and by 
implication investment. Financial Inclusion indicators had a positive impact on growth but had to be coupled with financial development[25]. Similarly, [26]found out that various dimensions of Financial Inclusion promoted economic growth. The [27] argued that by lowering constraints to access to credit and lowering participation cost to market for firms and companies could generally boost growth and productivity and reduce inequality in African emerging and developing countries if all are financially included. In a related view, [28] studied the effects of Financial Inclusion on economic growth in Nigeria. He found a significant positive relationship between FI and economic growth. The author also showed that FI greatly influenced poverty reduction and financial intermediation through positively impacted Bank Branch Networks, Loans to rural areas and small enterprises. A well-functioning financial system serves a vital purpose by offering savings, which helps households manage cash flows, finances, businesses and this increases the cash flow thus boosting economic growth. Further still, [29] asserted that financial inclusion helps people to diversify or increase the income stream in the house hold, provides liquidity/cash flow; absorbs shock of adversity by building assets, which enables client to cope with loss through consumption smoothing, thus avoiding the sale of productive assets. Financial inclusion improves the financial status and standard of living of the poor and vulnerable, as it enables them to increase their engagement in economic activities, increase wealth and support employment of household members[30]. Financial inclusion is noted to play a significant role in promoting economic growth as many authors refer to it as a driving force to poverty reduction [31,3].Similarly,[32] observed that financial inclusion accelerates the flow of credit to smallScale enterprises, which serves as a new engine of sustaining small-scale enterprises growth and balanced development, because credit provides a significant source of employment and income to the rural dwellers. According to [33, 34]financial inclusion enhances efficient allocation of resources through financial intermediation. Financial intermediation is the movement of money from those who have excess to those who have shortage. The movement of money to those who make use of it improves resource allocation efficiency, especially in rural areas.

Allowing broad access to financial services, without price or non-price barriers to their use is likely to benefit the poor people and other disadvantaged groups through better access to credit which enables them to pull themselves out of poverty and support economic growth [1]. Similarly there is a link between financial inclusion and micro economic stability through capitalization and growth of new non-financial firms. This notion is further supported by [36], who argues that financial development is associated with more efficient allocation of capital. At the same time, [37]noted that Financial Inclusion was a key determinant of sustainable and inclusive growth which could bring out exceptional untapped potential of savings, consumption and investment propensities of the poorer sections of society. Similarly, [21]observed that Financial Inclusion and development has come up with a view that socio economic factors like income inequality, literacy and Urbanization are important factors that have an effect on Financial Inclusion. According to [38] several indicators of financial inclusion and the authors argued that financial inclusion should be measured by a comprehensive index of several indicators, such as access indicators, availability indicators as well as usage indicators, which would ensure an inclusive financial system, where all people will have the opportunity to participate in the growth process of a country. Similarly, [39] observed that Financial inclusion was a significant determinant of the factors of production, as well as capital per worker, which invariably determines the final level of output in the economy.

\subsection{Economic Growth}

Economic growth is the increase in income per capita of a country over a period of time. It's measured in the national productivity of a country which is reflected by the Gross Domestic Product (GDP) of a country per year. A study by [40] observed that Economic growth entails increases in per capita real gross domestic product (GDP), Viz broadening of the production scale in an entire country, or efficient usage of her economic resources to produce goods and services. Despite lower-than expected average income growth, Uganda has made substantial progress in improving household incomes and the proportion of the population living below poverty line fell to $19.7 \%$ from $21 \%$ [41]. Government supported Savings and Credit Cooperative Organizations (SACCO's) have enabled many households to grow their enterprises, particularly those that emerged to advance the common economic interest of a particular group[42]. Much emphasis has been put on addressing key constraints to production and productivity, marketing of agricultural products, access to finances and enhanced value addition through the development of agroindustries these are all geared towards supporting economic growth [42]. Accordingly, [28] examined the relationship between financial inclusion and economic growth and found out that there is a significant relationship between financial inclusion and economic growth in Nigeria in the period 1980-2012 by applying Ordinary Least Square (OLS) method. Similarly,[43]also studied the relationship between Financial Inclusion and economic growth in Kenya during the period 2002-2012. He used the OLS method to estimate the effect of financial inclusion proxied by (branch networks, number of mobile money users/accounts, number of automated teller machines in the country and bank lending rates) on economic growth proxied by Gross Domestic Product(GDP) growth. He found a positive impact on the variables of financial inclusion Viz. branches network and bank loan rate on economic growth. Using data from 1980-2014,[44]showed that financial inclusion has a positive effect on economic growth in the short run and long run. Similarly, [45] examined the economic impact of financial inclusion in India from gender perspective. Using panel data from 2007-2012, the author found a positive gender premier of effect of financial inclusion on 
income in favor of women. Specifically, financial inclusion programmes were found to increase incomes of women by $8.40 \%$ compared to $3.97 \%$ for men. A study by [46] observed that too much finance in developing countries as compared to that required for the potential needs of structural change, does not increase growth rate any further. It becomes negative when rapid growth in financial development is not accompanied by sufficient growth in real output. This complements the idea considered in [47]regarding the optimal structure of finance given the different development level of a country. Similar studies by [48, 49]stress that private credit towards firms and households can have different impact on economic growth. Research by [50] observed that financial instability has a negative impact on economic growth only in the short term. However, financial development affects economic growth positively in the short and long terms. In another view, [51]concluded that financial instability is detrimental to economic performance, with the effect of a financial crisis being more dangerous in less developed and closed economies due to the poor quality of institutions, compared to the liberalized and open economies of advanced countries. Liberalized financial systems can exhibit extreme volatility, resulting in financial crises which can have a dramatic impact on economic prosperity [52]. Financial instability in most cases would severely hamper the growth process of developing economies and this would also affect developed economies growth as well [53]it's therefore assumed that financial stability plays a positive role in a counties growth process. Accordingly, [49, 48] observed that access to credit by households and private firms can have different impact on economic growth. This therefore means that financing would facilitate economic growth indirectly through relaxation of working capital constraints, supporting additional investments, international trades and enhancement of investments in education [49]. Similarly [54]observed that access to finance stimulates economic growth, strengthens competitiveness and demand for labor. In line with income inequality, [12] asserted that income inequality is often the result of unequal economic opportunities and monopolized markets which often leads to the marginalization of the poor and financial inclusion would be low in countries with great income disparities. From African perspective,[55] observed that a constant and decreasing return to scale exist between technological progress, productivity and growth in Uganda. That is, an increase in the level of technology, capital stock and labor were found to increase economic growth.

\subsection{Financial inclusion and economic growth}

[56] investigated the role of financial inclusion on poverty reduction and economic growth in Africa. ATM, bank branches and government expenditures were found to be the most robust predictors for financial growth on poverty. A related study conducted in Turkey found that income is positively and significantly correlated with financial inclusion [57]. This study also established Turkey as having the lowest financial inclusion level among EU countries. Focusing on microfinance, [58]found that economic growth and development of a nation depend on the expansion of the banking and financial services to the currently financiallyexcluded class of citizens. In addition, the need to educate the public on the benefits of a financial superstructure remains necessary in developing countries. In Iraq, the nexus between financial inclusion and economic development found no relationship between financial inclusion indicators and economic growth during the period 1990 - 2016 [59]. More efforts were needed to enhance and extend the financial inclusion in Iraq through financial literacy, consumer protection and providing financial services to low income people. Exploring the effect of financial institutions access and financial markets access on economic growth in transition economies of Central and Eastern European Union during 1996-2014, a significant causal interaction was revealed only between financial markets access and economic growth[57]. This was contrary to the bilateral causality that is often reflected in literature. Using the overall rate of economic penetration of financial services and the overall rate of use of financial services to examine the causal relationship between financial inclusion and economic growth in West African Economic and Monetary Union (WAEMU), [60] found no causality between economic growth and financial inclusion indicators at the scale (1 -2 years). However, a bilateral causality was found between financial inclusion and economic growth at scale ( $4-8$ years). The study scope was 2006 to 2015. Hamad \& Zunaidah (2018) concluded that optimistic views for financial inclusion on growth based on accessibility of financial services include expansion of bank branches, minimizing barriers in access to fiancé and contribution to the banking sector. Otherwise, studies that confirmed negative or weak contribution of financial inclusion on growth are conducted in economies where the financial systems are weak, and low availability of financial systems.

\section{METHODOLOGY}

The study used a cross-sectional survey design. Both quantitative and qualitative approaches were used in data collection and analysis. This was chosen to ensure that the study accurately described the true nature of the existing conditions at an explicit point in time. The study used simple random and purposive sampling techniques to select a total of 194 respondents to collect the data. Data was collected from the districts of Mbarara (55), Kasese (44), Kabale (45) and Fort Portal (50) respectively. The choice of the number of respondent's depended on the average population of each district under study. The study employed both descriptive and correlation analysis. Descriptive analysis was adopted to identify and obtain the contributions of financial inclusion on economic growth. Self-administered questionnaires were used to enable each participant have adequate time to reflect and respond to the same questions in a predetermined order. A 5-point Likert scale was used ranging from 1-5 where 1(strongly 
disagree), 2(disagree), 3(not sure), 4(agree), 5(Strongly agree). Correlation analysis was used to establish the relationship between the constructs.

\section{RESULTS}

Table 1.Reliability Statistics

\begin{tabular}{lccc}
\hline \hline Variable & Cronbach's Alpha & $\begin{array}{c}\text { Cronbach's Alpha Based on } \\
\text { Standardized Items }\end{array}$ & N of Items \\
\hline Financial inclusion & .779 & .781 & 20 \\
Economic growth & .672 & .676 & 21 \\
Over all & $\mathbf{0 . 7 2 6}$ & $\mathbf{0 . 7 2 9}$ & $\mathbf{4 1}$ \\
\hline \hline
\end{tabular}

\section{Source: Field data, 2019}

Examining the reliability of the items used, Cronbach's Alpha coefficient was used to examine the internal consistency. Accordingly, $(\alpha=.726)$, which was above the acceptable 0.7 indicated that the items were internally stable and adequate for generalization of results. High consistency was evident in items on financial inclusion $(\alpha=.781)$ than items on economic growth $(\alpha=.672)$. This could be attributed to the difficulty associated to measuring economic growth and the abstract indicators of economic growth.

Table 2.Background characteristics

\begin{tabular}{llcc}
\hline \hline Variable List & Categories & Frequency & Percent \\
\hline Gender & Male & 113 & 66.1 \\
& Female & 58 & 33.9 \\
& Total & 171 & 100 \\
\hline Age & $20-35$ & 52 & 30.4 \\
& $36-50$ & 92 & 53.8 \\
& 50 and above & 27 & 15.8 \\
& Total & 171 & 100 \\
\hline Marital status & Single & 69 & 40.4 \\
& Married & 94 & 55 \\
& Others & 8 & 4.7 \\
& Total & 171 & 100 \\
\hline Highest level of education & Primary & 34 & 19.9 \\
& Secondary & 88 & 51.5 \\
& Tertiary & 49 & 28.7 \\
& Total & 171 & 100 \\
\hline \hline
\end{tabular}

\section{Source: Field data, 2019}

The participation according to gender indicates that $66.1 \%$ were male while $33.9 \%$ were female. This still is suggestive of low levels of women financial inclusion and their participation in economic growth. The distribution across gender could be attributed to the extent to which men were more accessible than the women. According to age distribution, $30.4 \%$ were youths, $53.8 \%$ were adults while $15.8 \%$ were old. The statistics on age indicate how the zeal youths have to reduce poverty and unemployment, though structural and institutional factors do not favor them at times. This distribution suggests the fact that the most accessible population constituted the adults, most of whom were found working and managing their businesses. A variation in marital status indicates that $40.4 \%$ were single, $55 \%$ were married while $4.7 \%$ indicate the 'others' option. The statistics suggest that most of the participants were married with additional roles in their families. The statistics on marital status are suggestive of economic and dependency burdens, which mares most of the families in rural Uganda. Examining the variations in their highest level of education, $51.5 \%$ had secondary education, $28.7 \%$ had tertiary education while $19.9 \%$ had primary education. The variations in age suggests that most of the participants had adequate level of understanding to respond to the issues raised in this questionnaire.

Table 3. Factor Analysis: Financial inclusion 


\begin{tabular}{llc}
\hline \hline Variable List & $\mathbf{1}$ & $\mathbf{2}$ \\
\hline 1. I find it easy accessing affordable financial services & 0.552 \\
2. I normally go financial services that are relevant to my needs & 0.605 \\
3. Access to financial services has transformed my way of living & 0.563 \\
4. Access to financial services promotes equitable distribution of growth benefits & 0.571 \\
5. Access to financial services has enhanced my capital creation & 0.523 \\
6. Access to financial services has grown my savings & 0.589 \\
7. Access to financial services has increased my participation in the market & 0.698 \\
8. Access to financial services is one way to reduce income inequality in the country & 0.685 \\
9. Access to financial services can support poverty reduction & 0.55 \\
10. Those with access to financial services enjoy a high financial status & 0.507 \\
\hline 11. Total & 4.15 & 2.48 \\
12. \% of Variance & 20.77 & 12.39 \\
13. Cumulative \% & 20.77 & 33.17 \\
\hline KMO Measure of Sampling Adequacy. & 0.733 \\
Bartlett's Test of Sphericity & \multicolumn{2}{l}{} \\
Approx. Chi-Square & 835.3 \\
Df & 190 & \\
Sig. & 0.00 & \\
\hline \hline
\end{tabular}

\section{Extraction method: principle analysis}

Using the data reduction procedure of data analysis, $\mathrm{KMO}$ measure of sampling adequacy $(\mathrm{KMO}>.50)$ is suggestive that running a factor analysis is important in analyzing the behavioral of economic growth. Bartlett's test of sphericity (sig. <.05) is suggestive that the variable indicators extracted have significant relationships amongst themselves. This point to the suitability of the extracted data for factor analysis. However, the extraction suggests that the extracted variables account for $33.2 \% \%$ of the original data variables. Average factor were apparent in how access to financial services increase participation in the market $(r=.698)$, access to financial services reduce income inequality in the country $(\mathrm{r}=.685)$ and how access to financial services has grown people's savings $(\mathrm{r}=.589)$.

Descriptive statistics on financial inclusion indicates two distinct extents, that is (mean $\geq 3.500)$, which is moderately high; $(2.500$ $\leq$ mean $<3.500$ ), which is moderate and (mean $<2.500$ ), which is low. Moderately high opinions indicated that access to financial services promotes equitable distribution of growth benefits (mean $=3.89$ ), transforms peoples' way of living ( mean $=3.84$ ), enhances peoples' capital creation (mean $=3.78$ ), and enable people to go financial services that are relevant to their needs (mean $=3.68)$. Moderate opinions indicated that access to financial services supports poverty reduction $($ mean $=3.42)$ and enables people with access to financial services to enjoy a high financial status (mean $=3.26$ ).

Table 4. Descriptive Statistics: Financial inclusion

\begin{tabular}{|c|c|c|}
\hline Variable List & Mean & $\begin{array}{c}\text { Std. } \\
\text { Deviation }\end{array}$ \\
\hline 1. Access to financial services promotes equitable distribution of growth benefits & 3.89 & .997 \\
\hline 2. Access to financial services has transformed my way of living & 3.84 & .873 \\
\hline 3. Access to financial services has enhanced my capital creation & 3.78 & .999 \\
\hline 4. I normally go financial services that are relevant to my needs & 3.68 & 1.009 \\
\hline 5. Access to financial services has increased my participation in the market & 3.65 & 1.130 \\
\hline 6. Access to financial services has grown my savings & 3.63 & 1.213 \\
\hline 7. Access to financial services is one way to reduce income inequality in the country & 3.52 & 1.150 \\
\hline 8. Access to financial services can support poverty reduction & 3.42 & 1.202 \\
\hline 9. Those with access to financial services enjoy a high financial status & 3.26 & 1.120 \\
\hline 10. I find it easy accessing financial services & 2.29 & 1.344 \\
\hline Average & 3.5 & 1.104 \\
\hline
\end{tabular}

Source: Field data, 2019 
On the other hand, low opinions on financial inclusion were indicated on the fact that people find it easy to access financial services (mean =2.29). In line with consistency in opinions raised on financial inclusion, participants appeared to be consistent in their opinions on access to financial services transforming their way of living (Std. dev. =.873), promoting equitable distribution of growth benefits (Std. dev. =.997) and enhancing capital creation. Notwithstanding, divergent opinions remained in participants finding it easy to access financial services (Std. dev. $=1.344)$ and access to financial services growing their savings $($ Std. dev. $=1.212$ ).

Table 5. Factor Analysis: Economic Growth

\begin{tabular}{|c|c|c|c|c|c|}
\hline Variable List & 1 & 2 & 3 & 4 & 5 \\
\hline 1. ATMs are widely scattered all over the country & & & & & 0.807 \\
\hline 2. Production in Uganda has increased & & & & 0.795 & \\
\hline $\begin{array}{l}\text { 3. This country effectively uses economic resources to produce goods } \\
\text { and services }\end{array}$ & & & & 0.618 & \\
\hline 4. The government of Uganda has programs that support investment & & & 0.567 & & \\
\hline 5. Uganda has programs that support international trade & & & 0.669 & & \\
\hline 6. Uganda's population that lives below poverty line is falling & & 0.535 & & & \\
\hline $\begin{array}{l}\text { 7. Uganda has generally reduced constraints to marketing agricultural } \\
\text { products }\end{array}$ & & 0.559 & & & \\
\hline $\begin{array}{l}\text { 8. Uganda has generally reduced constraints to access to financial } \\
\text { services }\end{array}$ & & 0.503 & & & \\
\hline 9. Bank lending rates in Uganda are generally affordable & 0.527 & & & & \\
\hline 10. Uganda's financial system is highly liberalized & 0.631 & & & & \\
\hline 11. There is generally reduced constraints to working capital & 0.578 & & & & \\
\hline Total & 3.46 & 2.89 & 2.65 & 1.53 & 1.25 \\
\hline$\%$ of Variance & 16.49 & 13.75 & 12.6 & 7.27 & 5.96 \\
\hline Cumulative $\%$ & 16.49 & 30.24 & 42.84 & 50.12 & 56.08 \\
\hline KMO Measure of Sampling Adequacy. & 0.7 & & & & \\
\hline \multicolumn{6}{|l|}{ Bartlett's Test of Sphericity } \\
\hline Approx. Chi-Square & 1056.9 & & & & \\
\hline Df & 210 & & & & \\
\hline Sig. & 0 & & & & \\
\hline
\end{tabular}

Extraction method: principle analysis

Using the data reduction procedure of data analysis, KMO measure of sampling adequacy (KMO > .50) is suggestive that running a factor analysis is important in analyzing the behavioral of economic growth. Bartlett's test of sphericity (sig. <.05) is suggestive that the variable indicators extracted have significant relationships amongst themselves. This points to the suitability of the extracted data for factor analysis. In addition, the extraction suggests that the extracted variables account for $56.08 \%$ of the original data variables. Very high factor loadings were evident in ATMs being widely scattered all over the country $(\mathrm{r}=.807)$, increase in production $(\mathrm{r}=.795)$, Uganda having programs that support international trade $(\mathrm{r}=.669)$ and Uganda having a financial system that is highly liberalized $(\mathrm{r}=.631)$. 
Table 6.Descriptive Statistics: Economic Growth

\begin{tabular}{|c|c|c|}
\hline Variable List & Mean & $\begin{array}{c}\text { Std. } \\
\text { Deviation }\end{array}$ \\
\hline 1. Uganda's population that lives below poverty line is falling & 4.03 & .785 \\
\hline 2. There is generally reduced constraints to working capital & 3.98 & .955 \\
\hline 3. Uganda has generally reduced constraints to access to financial services & 3.87 & .872 \\
\hline 4. Uganda's financial system is highly liberalized & 3.87 & .939 \\
\hline 5. This country effectively uses economic resources to produce goods and services & 3.78 & 1.093 \\
\hline 6. Production in Uganda has increased & 3.66 & 1.174 \\
\hline 7. Bank lending rates in Uganda are generally affordable & 3.66 & .977 \\
\hline 8. Uganda has generally reduced constraints to marketing agricultural products & 3.64 & .998 \\
\hline 9. ATMs are widely scattered all over the country & 3.50 & 1.262 \\
\hline 10. The government of Uganda has programs that support investment & 2.95 & 1.287 \\
\hline 11. Uganda has programs that support international trade & 2.57 & 1.188 \\
\hline Average & 3.59 & 1.048 \\
\hline
\end{tabular}

Source: Field data, 2019

Descriptive statistics on economic growth indicates three distinct groups of view and opinions, that is high (mean $>4.000$ ), average $(3.500 \leq$ Mean $\leq 4.000)$, and below average (mean < 3.500). Participants consistently indicate a high view point that Uganda's population that lives below poverty line is falling (mean $=4.03$; Std. dev. =.785). This can be reflected in the reduced constraints to accessing working capital (mean $=3.98$ ), reduced constraints to access to financial services, which associated to the liberalized financial system (mean $=3.89)$, the effective use of economic resources to produce goods and services $($ mean $=3.78)$, the general increased production, which in part is associated to the generally affordable lending bank rates $($ mean $=3.66)$ and the reduced constraints to marketing agricultural products both locally and internationally (mean $=3.64$ ). However, Uganda's programs that support international trade (mean $=2.57)$, investment $($ mean $=2.95)$ and the wide scattering of ATMs all over the country reflect low economic growth.

From the descriptive statistics above it is evident that financial inclusion (mean $=3.5 ;$ std. $=1.104)$ and economic growth $($ mean $=$ 3.59 ; std. $=1.048$ ) suggest that businesses in the districts investigated are on average taking advantage of the existing financial services. Similarly, the statistics on economic growth suggest an average economic growth base in the districts investigated. And while there weren't significant differences expressed in participants' understanding of financial inclusion and economic growth, the above statistics were inadequate to explain the real effect of financial inclusion on economic growth. The regression model was deemed necessary.

Table 7.Regression model

\begin{tabular}{|c|c|c|c|c|c|}
\hline & \multicolumn{2}{|c|}{$\begin{array}{c}\text { Unstandardized } \\
\text { Coefficients }\end{array}$} & \multirow{2}{*}{$\begin{array}{c}\begin{array}{c}\text { Standardized } \\
\text { Coefficients }\end{array} \\
\text { Beta }\end{array}$} & \multirow{2}{*}{$\begin{array}{r}\mathbf{t} \\
\mathbf{B}\end{array}$} & \multirow{2}{*}{$\begin{array}{c}\text { Sig. } \\
\text { Std. } \\
\text { Error }\end{array}$} \\
\hline & B & $\begin{array}{l}\text { Std. } \\
\text { Error }\end{array}$ & & & \\
\hline (Constant) & 3.040 & 0.208 & & 14.599 & 0.000 \\
\hline Financial Inclusion & 0.165 & 0.059 & 0.212 & 2.818 & 0.005 \\
\hline $\mathrm{R}$ & 0.212 & & & & \\
\hline R Square & 0.045 & & & & \\
\hline Adjusted R Square & 0.039 & & & & \\
\hline Std. Error of the Estimate & 0.371 & & & & \\
\hline Regression sum of squares & 1.091 & & & & \\
\hline Residual sum of squares & 23.219 & & & & \\
\hline
\end{tabular}

a: Predictors: (Constant), Financial Inclusion

b: Dependent Variable: Economic Growth 
It can be observed that the relationship between financial inclusion and economic growth $(\mathrm{r}=.212)$ is significant but very weak. This suggests that as government increases her efforts in ensuring that even the very poor have access to financial services, the effect on economic growth is very low. The (Adjusted R Square $=0.045$ ) suggests that financial inclusion can only account for only $4.5 \%$ of the variation in the level of economic growth as indicated by the study participants. The low percentage contribution of financial inclusion in the level of economic growth is suggestive of a number of factors that highly explain variations in economic growth in any economy. Regression sum of squares (1.091) is smaller than the Residual sum of squares (23.219), which suggests that this model is not adequate in explaining the level of variation in economic growth accounted for by financial inclusion. It should be noted that the sig. value for the t-statistic is 0.005 , which is less than 0.05 suggests that financial inclusion has a significant effect on economic growth when measured at $5 \%$ level of significance.

\section{DISCUSSION}

The study indicated moderate opinions on the fact that access to financial services promotes equitable distribution of growth benefits. The findings agree with [23] who observed that financial sector development promotes pro-poor and equitable economic growth. When people have access to financial services, the chances of borrowing for injecting into business are high, though some might borrow for luxurious spending. The study found that financial inclusion transforms peoples' ways of living, which supports [30]who noted that financial inclusion improves the financial status and standards of living of the poor and vulnerable as it increases their engagement in economic activities, wealth creation and employment of household members. In line with wealth creation, the study indicated that financial inclusion enhances people's capital creation, which agrees with [24] who observed that financial inclusion has the potential to enhance economic growth since financial sector savings and intermediation imply investment. In the same view, the study further indicated that financial inclusion enables people to access financial services that are relevant to their needs. The findings support [19] who noted that for an individual to get proper benefits of financial products and services, all should be accessible, cheap and relevant to individual needs. This view point suggests that the people investigated in this study appreciated the role of financial inclusion to solving personal and individualized needs.

The study indicated moderate opinions on financial inclusion supporting poverty reduction and enabling people to enjoy high financial status. The findings deviate from [28] who investigated the relationship between financial inclusion and economic growth and showed that financial inclusion greatly influences poverty reduction. Onaolop's study was conducted in Nigeria, which is a step ahead of Uganda in terms of economic growth. In Uganda, financial inclusion has aggregately supported poverty reduction in a minority class of people. At household level however, poverty in Uganda is still evident and is on the increase. The possibility of poverty increase amidst financial inclusion is a policy dilemma. Liberalization of the financial sector exposed rural peasants to financial sharks, who have scrupulously squandered the economic growth potentials of the poor. This is a policy issue that require review and urgent attention by the monitoring institutions of the financial sector. In the same line, the findings indicated low positions on people finding it easy to access financial services. The findings support [61] who conducted a study on Financial accessibility and poverty reduction in Lango sub region and found a weak effect of financial accessibility on poverty reduction. This study found isolated pockets of poverty reduction even among those with access to financial resources.

The study was highly consistent that Uganda's population living below poverty line is falling. This disagrees with [41]who observed that the proportion of poor people in Uganda increased to 21.4\% in 2016/17 from 19.7\% in 2012/2013. Similarly, [41] reported that more Ugandans were increasingly slipping into poverty from 6.6 million in 2012/2013 to 10 million in $2016 / 17$. The study indicated reduced constraints to accessing financial services, which is a product of the highly liberalized financial system. The findings disagree with [52]) who observed that a liberalized financial system can exhibit extreme volatility, resulting in financial crises, which can have dramatic impact on prosperity. Participants indicated low opinions on Uganda having programs that support international trade, which disagrees with [62] who recommended support for international trade, investment in education, relaxation of working capital constraints and supporting additional investment as facilitators to economic growth indirectly.

The findings indicated a very weak relationship between financial inclusion and economic growth, disagrees with [54] which found that access to finance stimulates economic growth, strengthens competitiveness and demand for labor. Similarly, [51] observed the low effect of financial inclusion on economic growth in developing economies to be attributed to poor quality of institutions as compared to the liberalized and open advanced economies of the developed world. Similarly, [63]in their article on financial literacy, cash management and business growth in Kampala Capital City Authority, Uganda noted that the availability of free and cheap credit, which is sometimes picked without aligning it to business objectives has often caused bankruptcy of many businesses as the owners tend to use borrowed funds for improving standards of living. 


\section{CONCLUSION}

The study was conducted to examine the role of financial inclusion in economic growth basing on selected districts from western Uganda. This study established that financial inclusion is significant in supporting economic growth but its effect is very scrawny. In view of its contributive role in economic growth, financial inclusion upholds equitable distribution of growth benefits, transforms peoples' way of living, enhances capital creation and empowers people to go for financial services that are germane to their needs. These benefits would pinnacle the view that financial access to financial services supports poverty reduction. Despite that superficially high role played by financial inclusion in economic growth, few Ugandans find it easy to access financial services. In view of economic growth dimensions, the study indicated that Uganda's population living below poverty line is falling, which sounds precise in the context of national income but very unseemly in the context of household income. Many Ugandan are eking out a living. While there are indicators of reduced constraints to access to working capital, reduced constraints to accessing financial services, effective use of economic resources to produce goods and services, those in business do not see the efficacy government agendas geared to supporting international trade or investment.

\section{RECOMMENDATIONS}

The study found government programs and policies ineptitude on international trade and investment. There is need for government to review and redesign her policies on international trade business and support for homegrown investments. The study also found that Uganda's population below poverty line is falling. There is need for quantitative metrics to ascertain the extent to which household income in proportion to national income. Several papers have recommended government interventions in financial accessibility. While there are many players in the financial services industry, people still find it hard to access this service, especially the rural poor, who lack the collateral to guarantee the security of the loans they would go for. More than often, the rural poor have lost their assets to scrupulous money lenders who promise cheap credit. Like in other papers, government, should strengthen her fiduciary roles in the economy. This paper brings to theory and practice new knowledge on financial inclusion and its perceived role in supporting economic growth in Uganda.

\section{REFERENCES}

[1] D. K. Asli and D. Klapper, Measuring Financial Inclusion, the Global Findex Database, World Bank, 2014.

[2] J. Bagyenda, "Bank of Uganda and Financial Inclusion," Financial Literacy Newsletter, no. Issue 1, pp. 1-2, 26 July 2013.

[3] D.-K. Cull and Morduch, The economic impact of expanding access to finance in Mexico, Mexico, 2012.

[4] World Bank, Global Financial Development report 2014: Financial Inclusion, Washington, DC : World Bank. , 2014.

[5] B. Alam and S. Sami, "Role of banks in financial inclusion in India," vol. Volume 62, no. Issue 2 , pp. 644-656, 2017 .

[6] N. Mehrotra, Financial Inclusion: An overview., Mumbai: National Bank for Agriculture and Rural Development, Department of Economic Analysis \& Research, 2009.

[7] M. Brownbridge, C. Harvey and A. F. Gockel, Banking in Africa: The Impact of financial sector reforms since Independence, Oxford: J.Currey, 1998.

[8] A. Whitworth and T. Williamson, Overveiw of Uganda Economic reform Since 1986: In Uganda's Economic Reforms Insider Accounts., New York, NY: Oxford University Press, 2010.

[9] L. Katusiime, Three Empirical Essays on the Ugandan Foreign Exchange Market: PhD thesis., New Castle : University of Newcastle, 2015.

[10] Uganda Economic Update, Financial Growth and Development Options for Raising More Domestic Revenue., 2018. 
[11] Bank of Uganda , "Bank of Uganda, State of the Economy," September 2018 . [Online]. Available: www.worldbank.org/en/en/country/uganda/overview.

[12] S. Ssewanyana and L. Bategeka, Chronic poverty and economic growth in Uganda. CPRC., Research for BASIS collaborative Research Support Program, 2007.

[13] Bank of Uganda, Financial Inclusion project Strategy Paper, Bank of Uganda, 2013.

[14] O. P. Ardic, M. Heimann and N. Mylenko, Access to financial services and financial inclusion agenda around the world: A cross-country analysis with a new data set., World Bank, 2011.

[15] A. Demirguc-Kunt and L. Klapper, Measuring Financial Inclusion, The Global Findex Database, 2012.

[16] S. Johnson and M. Nino-Zarazua, "Financial access and exclusion in Kenya and Uganda.," The journal of Development studies, vol. 47, no. 3, pp. 475-496, 2011.

[17] G. W. Ssonko, The role of Mobile Money Services in enhancing Financial Inclusion in Uganda., Kampala: Bank of Uganda, 2010.

[18] FINSCOPE, Uganda Finscope III survey report findings, Economic policy research centre, 2013.

[19] L. Kasekende and M. Brownbridge, "Post-crisis Monetary policy frameworks in Sub- Saharan Africa.," African Development Review, vol. 23, no. 2, pp. 190-201, 2011.

[20] P. Dupas, D. Karlan and J. Robinson, Expanding Access to Formal Savings accounts in Malawi, Uganda, Chile and the Philippines., New Haven, Conn: Innovations for poverty Actions, 2013.

[21] M. Sarma and J. Pais, "Financial Inclusion and Development," Journal of International Development, vol. 23, no. 5, pp. 613-628, 2011.

[22] P. J. Christabell and R. A. Vitmal, "Financial Inclusion in Rural India: the Role of Microfinannce as a tool," IOSR Journal of Humanities and Social Science, vol. 2, no. 5, pp. 21-25, 2012.

[23] World Bank, Finance for all? Policies and Pitfalls in expanding access, Washington, DC: World Bank, 2008.

[24] K. C. Chakrabarty, "Inclusive growth- Role of Financial Sector," in Address at the National Finance Conclusive 2010 , Bhubaneswar, 2010 .

[25] D. Johnston and M. Jonathan, "The Unbanked: Evidence from Indonesia," World Bank Economic Review , vol. 22, pp. 517-37, 2008.

[26] A. Hannig and S. Jansen, "Cross-Country Variation in Household Access to Financial Services," in Hannig, A \& Jansen, S (2010). "Cross-Country VariWorld Bank Paper Conference on Access to Finance, Washington DC, 2010.

[27] G. Hariharan and M. Marktanner, The growth potential from Financial Inclusion, ICA Institute and Kennesaw State University., 2012.

[28] R. Sahay, M. Cihak, P. N'Diaye, A. Barajas, S. Mitra, A. Kyobe and S. R. Yousefi, "Financial Inclusion: Can it meet multiple macroeconomic goal?," Sahay,R., Cihak, M., N'Diaye,P., Barajas,A., Mitra,S., Kyobe,A..

Yousefi,SInternational Monetary Fund, 2015.

[29] D. Sharma, "Nexus between Financial Inclusion and Economic Growth: Evidence from the emerging Indian economy," Journal of Financial Economic Policy, vol. 8, no. 1, pp. 13-36, 2016.

[30] Outlook Regional Economic , "Sub-Saharan Africa: Dealing with the gathering clouds," International Monetary 
International Journal of Advances in Scientific Research and Engineering (ijasre), Vol 5 (10), October-2019

Fund. , 2015.

[31] A. R. Onaolop, "Effects of Financial Inclusion on the Economic Growth of Nigeria (1982-2012)," International Journal of Business and Management Review, vol. 3, no. 8, pp. 11-28, 2015.

[32] H. Clark, " Financial Inclusion and HIV/AIDS: Some issues for consideration for the workshop on MicroFinance and HIV/AIDS," Journal of Parker, vol. 2, no. 3, pp. 23-26, 2013.

[33] S. R. Khan, Fighting Poverty with Microcredit: Experience of the Grameen Bank and Other Programmes In Bangladesh., Washington DC: World Bank, 2011.

[34] A. Raman, "Financial Inclusion and Growth of Indian Banking System," IOSR Journal of Business and Management (IOSRJBM), vol. 1, no. 3, pp. 25 - 29, 2012.

[35] F. O. Okafor, "Financial Inclusion: An Instrument for Economic Growth and Balanced Development in Rural Areas," Journal of the Chartered Institute of Bankers of Nigeria, vol. 6, no. 8, pp. 38-45, 2012.

[36] A. Goodland, G. Onumah and J. Amadi, Rural Finance., Chatham, U.K: Natural Resource Institute, 2012.

[37] J. Yaron, M. P. Benjamin and G. L. Piprek, Rural Finance: Issue, Design and Best Practices, Washington, DC: The World Bank, 2013, pp. Yaron, J., Benjamin, M,P., and Piprek, G.L (2013) Rural Finance: Issue, Design and Best Practices., Washington DC, The World Bank..

[38] J. Wurgler, "Financial markets and allocation of capital.," Journal of financial economics, 2000.

[39] P. Mukherji, "Finacial-inclusion-unbanked-population-financial-services," November 2014. [Online]. Available: http://articles.economictimes.indiantimes.com.

[40] M. N. A. Siddik, G. Sun and S. Kabiraj, "Financial Inclusion and its determinants: a study of Bangladesh," FinIndian Journal of Finance, vol. 9, no. 6, pp. 7-29, 2015.

[41] A. B. Abiola, B. A. Folasad and E. O. Alexander, "Financial Inclusion and Economic Growth in Nigeria," International Journal of Economics and Financial Issues., vol. Vol. 5 , no. Issue 3,, 2015.

[42] A. Kibricioglu and S. Dibooglu, Long-run Economic growth: An interdisciplinary approach, University of Illinois at Urbana-Champaign, 2001.

[43] Uganda Bureau of Statistics, "Uganda National Household Survey 2016/17," Uganda Bureau of Statistics, Kampala, 2017.

[44] IMF , Poverty Reduction Strategy Paper- Progress Report., Washington D.C: International Monetary Fund, 2014.

[45] J. Oruo, The relationship Between Financial Inclusion and GDP Growth in Kenya., Nairobi: University of Nairobi , 2013.

[46] S. K. Lenka and R. Sharma, "Does Financial Inclusion Spur Economic Growth in India?," The Journal of Developing Areas, vol. 51, no. 13, pp. 215-228, 2017.

[47] V. Swamy, "Financial Inclusion, gender dimension and economic impact on poor households.," World development, vol. 56, pp. 1-15, 2014.

[48] L. Ductor and D. Grechyna, "Ductor, L., Grechyna, D. (2015). Financial Development, real sector, and economic growth. International Review of Economics and Finance 37,393-405," International Review of Economics and Finance, vol. 37 , pp. 393-405, 2015. 
[49] A. Demirguc-Kunt, E. Feyen and R. Levine, "The evolving importance of banks and securities markets.," World Bank Economic Review, vol. 27, pp. 476-490, 2013.

[50] B. Cournede, O. Denk and P. Hoeller, Finance and Inclusive growth., Paris: OECD Publishing, 2015.

[51] T. Beck, B. Buyukkarabacak, F. Rioja and N. Valev, "Who gets the credit? And does it matter? Household Vs Firm lending a cross countries.," B.E Journal of Macroeconomics Contributions, 12,1-44., vol. 12, pp. 1-44, 2012.

[52] C. Eggoh, Financial Development, Financial Instability and Growth: A Reappraisal, Eggoh, C. (2008). "Financial DevelopmentLaw, Economic and Management Faculty, University or Orleans, 2008.

[53] A. Bonfiglioli and C. Mendicino, Financial Liberalization, Banking Crises and Growth: Assessing the links, Stockholm , 2004.

[54] A. Dimitras, M. Kyriakou and G. Latridis, "Financial Crisis, GDP variation and earning management in Europe," Dimitras, A., Kyriakou, MResearch in International Business and Finance, vol. 34, pp. 335-338, 2015.

[55] J. Creel, P. Hubert and F. Labondance, "Financial Stability and Economic Performance," Economic Modeling, vol. 48, pp. 25-40, 2015.

[56] World Bank, Global Financial development report: Rethinking the role of the state in finance, 2013.

[57] J. Alani, "Effects of technological progress and productivity on economic growth in Uganda," Procedia economics and Finance, vol. 1, pp. 14-23, 2012.

[58] H. W. Tega, A. J. Adegoke and D. Adegbola, " The role financial inclusion in economic growth and poverty reduction in a developing econmy. International Journal of Research in Economics and Social Sciences, 7(5), 265-271," The role financial inclusion in economic growth and poverty reduc International Journal of Research in Economics and Social Sciences, vol. 7, no. 5, pp. 265-271, 2017.

[59] R. Yorulmaz, "Financial inclusion and economic growth development: A case study of turkey and a crosscountry analysis of European Union," Clemson University, 2012.

[60] K. C. Otiwu, P. A. Okere, L. N. Uzowuru and P. N. Ozuzu, "financial inclusion and economic growth of nigeria (The Microfinance option)," International Journal forlinnovation Education and Research, vol. 6, no. 2, pp. 6174, 2018.

[61] H. K. Ammar and H. A. Azhar, "Financail inclusion and economic development in Iraq," International Journal of Science and Research, vol. 6, no. 10, pp. 1758-1767, 2017.

[62] A. Grakolet, G. Zamereith and P. Mendy, "Financial inclusion and economic growth in WAEMU: A multiscale heterogeneity panel causality approach," Munich Personal RePEc Archive, vol. MPRA Paper No. 82251, pp. 1$10,2017$.

[63] M. Eton, P. E. Odubuker, M. Ejang, B. P. Ogwel and F. Mwosi, "Financial Accessibility and Poverty Reduction in Northern Uganda, Lango Sub-Region.," International Journal of Social Science and Humanities Research, vol. 7, no. 2, p. $271-281,2019$.

[64] T. Beck, "Finance and Growth: lessons from the literature and the recent crisis, July 2012," Prepared for the LSE Growth Commission, 2012 .

[65] M. Eton, G. Barigye, M. Nyangoma, F. Mwosi and B. P. Ogwel, "Financial Inclusion and Women Empowerment in Uganda, a Case of Lango Sub-Region.," Economics, Commerce and Trade and Management. An International Journal (ECTIJ), vol. Vol. 2, no. No. 1, pp. 1-11, 2018.

[66] H. W. Tega, A. J. Adegoke and D. Adegbola, "The role financial inclusion in economic growth and poverty reduction in a developing econmy," International Journal of Research in Economics and Social Sciences, vol. 7, 
no. 5, pp. 265-271, 2017.

[68] B. Yilmaz and M. D. Gavriletea, "Financial inclusion and economic growth: Evidence from transition economies of European Union," Juornal of International finance and Economics, vol. 18, no. 2, pp. 95-100, 2018.

[69] O. B. Hamad and S. Zunaidah, "The role of financial inclusion on economic growth: theoretical and empirical literature review analysis," Journal of Business and Financial Affairs, vol. 7, no. 4, pp. 1-5, 2018.

[70] H. K. Ammar and H. A. Azhar, "Financail inclusion and economic development in Iraq.," International Journal of Science and Research, vol. 6, no. 10, pp. 1758-1767, 2017.

[71] M. Cihak and P. Singh, "An analysis of National Financial Strategies," 2013 . [Online]. Available: Cihak, M., \& Singh, P. (2013). An analysis of National Financial Strategies. http:// blogs.worldbank.org.

[72] A. Grakolet, G. Zamereith and P. Mendy, Financial inclusion and economic growth in WAEMU: A multiscale heterogeneity panel causality approach., 2017, pp. 1-10.

[73] O. B. Hamad and S. Zunaidah, "The role of financial inclusion on economic growth: theoretical and empirical literature review analysis.," Journal of Business and Financial Affairs, vol. 7, no. 4, pp. 1-5, 2018.

[74] K. C. Otiwu, P. A. Okere, L. N. Uzowuru and P. N. Ozuzu, "Financial inclusion and economic growth of nigeria (The Microfinance option)," International Journal forIinnovation Education and Research, vol. 6, no. 2, pp. 6174, 2018.

[75] R. Yorulmaz, Financial inclusion and economic growth development: A case study of turkey and a cross-country analysis of European Union, Clemson University, 2012.

[76] B. Yilmaz and M. D. Gavriletea, "Financial inclusion and economic growth: Evidence from transition economies of European Union. Juornal of International finance and Economics," Journal of International finance and Economics, vol. 18, no. 2, pp. 95-100., 2018. 